\title{
CONFERENCIA
}

\section{ANATOMÍA CLÍNICA DE LAS FUNCIONES CEREBRALES SUPERIORES- EPISTEMOLOGÍA Y METODOLOGÍA}

\author{
Gustavo H. R. A. OTEGUI \\ Departamento de Anatomía, Facultad de Medicina, Universidad de Buenos Aires, Buenos Aires, Argentina.
}

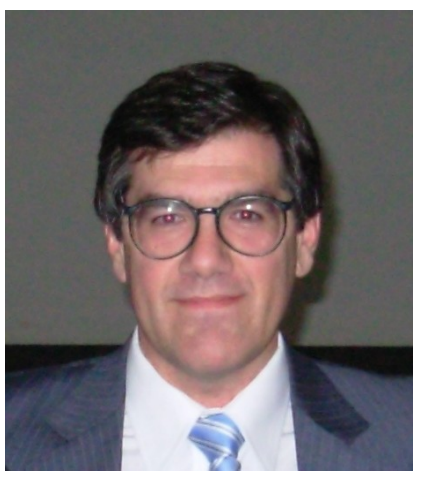

El objetivo de esta presentación es caracterizar en términos epistemológicos y metodológicos, la validez de los diferentes procedimientos morfológicos para estudiar las funciones cerebrales superiores, y el status científico de las áreas anatómicas responsables de las mismas.

El marco histórico reconoce dos supuestos: el localizacionismo, que propone la existencia de áreas cerebrales claramente delimitadas e interconectadas con otros sistemas; y el holismo, que niega la existencia de tales mapas cerebrales y supone que el cerebro como totalidad, es la única explicación posible de las funciones cerebrales superiores.

La metodología empleada a través de los años puede resumirse así:

a- Anatomía descriptiva, comparada y del desarrollo.

b- Disección de fascículos.

c- Anatomía imagenológica. d- Sección y tinción.

e- Neurofisiológicos.

f- Anatomía clínica y experimental.

Los resultados muestran que las funciones se correlacionan con la indemnidad de regiones determinadas del cerebro, y por tanto se afectan cuando esta región se destruye total o parcialmente. Discusión: el principal problema para abandonar definitivamente el holismo, parece residir en una inadecuada caracterización de los conceptos puestos en juego en la investigación. La vaguedad y la ambigüedad de éstos es un problema que no se resolverá con más aplicación de los métodos propios de las ciencias naturales, sino más bien con un desarrollo adecuada de la epistemología correspondiente.

Conclusión: el localizacionismo que defendemos supone el reconocimiento de áreas anatómicas especializadas en funciones determinadas. Las funciones constituyen propiedades emergentes de un determinado sistema cerebral. A poco que se analice nuestra propuesta se verá que es análogo al paradigma aceptado por la química, cuando estudia átomos, molécula y macromoléculas, o por la biología molecular, cuando busca los diferentes genes que codifican para diferentes caracteres del fenotipo. 